\title{
Online based Modernised Recruitment Process for Industries
}

\author{
G. Vinothini, R. Priya, S. Jayanthy
}

\begin{abstract}
Human Resources are, and thusly selecting, the most significant and imperative factor behind the accomplishment of each little and enormous association. E-recruiting or online recruitment is the selection of the best potential human resource using internet technology. Posting jobs on the company's website or online recruitment website and mobile recruitment has now evolved. This research explores the general basic concepts of e-recruiting, criteria for success, overall benefits and disadvantages.
\end{abstract}

\section{Keywords: E - Recruitments, Effectiveness}

\section{INTRODUCTION}

The entirety of the association's tasks to pull in the potential competitor are called E-Recruitment. It is a fundamental piece of overseeing $\mathrm{HR}$ as it satisfies the basic capacity of drawing in human cash-flow to the endeavor (Barber, 1998). The conventional strategy for enlisting, for example, putting promotions in papers, sitting tight for CVs, taking an interest in work entries, and so on., is vanishing by the section of web innovation[1]-[6]. The quick advance of innovation has profoundly changed the manner in which the organization is completed and this the utilization of innovation is unmistakably appeared by the quantity of associations and people who utilize the web and electronic mail (Erica, 2007). The patterns that make putting resources into the instruments for a fruitful e-enlistment procedure important for little and medium-sized endeavors are statistic patterns and budgetary shortage (Abra, 2009).

\section{A. Background of the study}

Typically, the nature of the contracted individuals is the key measurement for estimating the adequacy of the activity work, however in certain conditions, the employing pace may in truth be a progressively critical supporter of value enlisting. A decent profitable employing doesn't involve putting a promotion in the paper, setting up on the selected day a few seats and tables, and afterward taking a few resumes to catch up later[7]-[9]. The point of a contracting action is to connect with planned workers and get the association's one of a kind abilities and encounters, especially those that can not be developed. The inquiry is the means by

Revised Manuscript Received on December 11, 2019.

G. Vinothini, Department of Science and Humanities, Bharath Institute of Higher Education and Research, Chennai , India. Email: gvinothinibcom@gmail.com

R. Priya, Department of Science and Humanities, Bharath Institute of Higher Education and Research, Chennai , India. Email: rathi_priya83@yahoo.com

S. Jayanthy, Department of Science and Humanities, Bharath Institute of Higher Education and Research, Chennai , India. Email: Sjayanthy0903@gmail.com which to make this conceivable. Essential conventional enlistment starts with the handling of a solicitation structure. Accordingly, explicit prerequisites for occupations are set and an expected set of responsibilities is accommodated each position. Application structures and continues ought to be checked as the confirmation degree increments relying upon the significance of the situation to be filled. To wrap things up, execution tests and other evaluation helps can help the activity in the best individual[10]-[14]. This approach can take a lot of time and energy, however. The traditional hiring process (i.e., from job advertising to successful applicants hiring) has its own inherent weaknesses. Workplace ads alone can pose a problem. Print media ads (e.g. newspapers or magazines) is expensive. Consequently, the posting of work can only be advertised for a short time. In addition, the application system requires the applicant's physical presence to turn over the resume. This hinders the application of qualified job seekers who are still geographically separated. It is worth noting that there are 7,100 islands in the Philippines. Therefore, in today's competitive environment, old hiring methods may not be acceptable. An online recruitment system can address this issue. Virtual hiring will change the way businesses hire their workers[15]-[19]. As a basic business process, digital recruitment is the elimination of complicated and redundant paper works and the implementation of simplified management systems, robust software applications and effective channels of communication between job seekers and managers. "The Internet provides employers and job seekers with access to comprehensive and up-to-date information on job seekers and job vacancies in various locations around the world at a relatively low cost." In this way, businesses can agree to equal opportunities as a result of their work

\section{OBJECTIVES}

\section{A. Primary Objective \\ E- recruiting or online recruitment is the selection of the right potential human resource using internet technology.}

\section{B.Secondary Objective}

Posting jobs on the company website or on the recruiting platform and now mobile recruitment has developed from there.

The research explores the overall basic concepts of erecruiting, performance requirements, current patterns, general advantages and disadvantages. 


\section{RESEARCH METHODOLOGY}

Methodology of research can be understood as a science of how the research has been done scientifically. It is a way to systematically solve the research problem. Here, we study and analyze the various steps that are generally adopted by a researcher in studying his research problems[20]-[22].

\section{B. Research Design}

Research layout is a link between what was developed and what to do in conducting the survey in order to achieve the goal. This is a copy of data collection and calculation. CONVENIENT research model is the research design used in this study.

\section{RESULTS AND DISCUSSIONS}

- Nearly $80 \%$ of HR's are using social media for recruitment

- $90 \%$ of HR's are using E-recruitment for Naukri, other 5\% are using monster

- $98 \%$ of people suggest Naukri contains large number of resumes

- 85 percent of people believe that e-recruitment saves time

- -83 percent of people agree that it is the better way to collect performance resumes than the old method

- -74 percent agree that it is the organization's cost-saving practice

- 89 percent say that e-recruitment reduces the number of employees hired.

- Only $11 \%$ of the persons agreed E-Recruitment is used for recruiting people from small positions also like plumbers, $\mathrm{A} / \mathrm{c}$ mechanic, $89 \%$ of the persons said no

- Only through E-Recruitment the $80 \%$ of the candidates are closed

- $90 \%$ said only in consultancies E-Recruitment is higher

- $75 \%$ of the candidates are going for job without Absconding[23]-[25]

- $85 \%$ of the people agreed that less than or equal to 3 months people use to have People Engagement

\section{CONCLUSION}

The most of the recruiters are using Naukri for their sourcing, and it is very effective for them while comparing with Reference jobs still, the resumes come through reference will be less. And it is also find that E-recruitment finds to be the fastest mode and also quality resumes recruit through the profiles and also it reduces the selection cost also.

\section{REFERENCES}

1. Vasanthi, S. \& Rabiyathul Basariya, S. 2019, "Influence of value analysis and cross training in industry", International Journal of Engineering and Advanced Technology, vol. 8, no. 6, pp. 1810-1811.

2. Velvizhi, R., Sri Gowtham, S. \& Jeya Priya, D. 2019, "Examination of early feedbacks for effective product retailing on E-commerce websites", International Journal of Engineering and Advanced Technology, vol. 8, no. 6 Special Issue 2, pp. 703-706.

3. Anuradha, C., Pothumani, S. \& Kavitha, R. 2019, "A novel method towards E-commerce", International Journal of Engineering and Advanced Technology, vol. 8, no. 6 Special Issue 2, pp. 535-538.

4. Thomas, J. \& Rabiyathul Basariya, S. 2019, "A study on the issues of financial ratio analysis", Indian Journal of Public Health Research and Development, vol. 10, no. 3, pp. 1079-1081.

5. Ramachandran, S. \& Rabiyathul Basariya, S. 2019, "Online marketing study on customer satisfaction and relationship", Indian Journal of Public Health Research and Development, vol. 10, no. 3, pp. 1072-1078.
6. Priya, R., Vinothini, G. \& Cor Jesu, C.D. 2019, "The mentor-protégé relationship for professional growth", Journal of Advanced Research in Dynamical and Control Systems, vol. 11, no. 9 Special Issue, pp. 1110-1119.

7. Jannifer Rani, N., Bina Pani, S. \& Nimisha, N.S. 2019, "A study on money back polices available in LIC", Journal of Advanced Research in Dynamical and Control Systems, vol. 11, no. 9 Special Issue, pp. 833-839.

8. Saillaja, V., Jhansi Rani, K. \& Catherine, R. 2019, "Global marketing management planning and organization", Journal of Advanced Research in Dynamical and Control Systems, vol. 11, no. 9 Special Issue, pp. 489-493.

9. Saillaja, V., Jhansi Rani, K. \& Catherine, R. 2019, "The new phase of marketing information system", Journal of Advanced Research in Dynamical and Control Systems, vol. 11, no. 9 Special Issue, pp. $482-488$.

10. Thoufiqulla \& Raju, D.V. 2019, "Perception of indian investor towards investment in mutual funds with special reference to mip funds", Journal of Advanced Research in Dynamical and Control Systems, vol. 11, no. 5, pp. 177-183.

11. Jasmine, K.R.M. \& Basariya, S.R. 2018, "A study on the customers benefits on mutual funds", International Journal of Civil Engineering and Technology, vol. 9, no. 4, pp. 45-48.

12. Vasanthi, S. \& Basariya, S.R. 2019, "Pros and cons of on the job training versus off the job training", International Journal of Scientific and Technology Research, vol. 8, no. 10, pp. 671-674.

13. Pavithra, J. \& Ganesan, M. 2016, "A study on awareness and impact of micro-financial schemes", International Journal of Applied Business and Economic Research, vol. 14, no. 8, pp. 5449-5460.

14. 14. Pavithra, J., Dilli Babu, P. \& Ambuli, T.V. 2014, "A study on budgetary control at Maruti Service Masters, Chennai", International Journal of Applied Business and Economic Research, vol. 12, no. 2, pp. 151-161.

15. Gunaraja, T.M. \& Venkatrama Raju, D. 2018, "Determining factors of organisational climate with reference to leadership styles", International Journal of Mechanical Engineering and Technology, vol. 9, no. 9, pp. 1327-1332.

16. Gunaraja, T.M. \& Venkatrama Raju, D. 2018, "The role of job satisfaction and training of employees in determining organisational climate of a selected industry", International Journal of Civil Engineering and Technology, vol. 9, no. 8, pp. 1266-1269.

17. Aarathy, T.S. \& Raju, D.V. 2018, "Performance appraisal and its effects on employees with respect to it sector in Chennai city", International Journal of Civil Engineering and Technology, vol. 9, no. 6, pp. 1535-1538.

18. Aarathy, T.S. \& Raju, D.V. 2018, "Employee perception towards performance appraisal system in IT sector", International Journal of Mechanical Engineering and Technology, vol. 9, no. 5, pp. 131-135.

19. Porselvi, W., Jublee, D. \& Sivanesan, G. 2018, "A study on factors influencing adoption of technology and innovation in banking industry, tamilnadu, India", International Journal of Mechanical Engineering and Technology, vol. 9 , no. 5, pp. 789-800.

20. Akessa, G.M. and Dhufera, A.G., 2015. Factors That Influences Students Academic Performance: A Case of Rift Valley University, Jimma, Ethiopia. Journal of Education and Practice, 6(22), pp.55-63.

21. Miller, G. and Shih, C.C., 1999. A faculty assessment of the academic rigor of on-and off-campus courses in agriculture. Journal of Agricultural Education, 40, pp.57-65.

22. Tsinidou, M., Gerogiannis, V. and Fitsilis, P., 2010. Evaluation of the factors that determine quality in higher education: an empirical study. Quality Assurance in education, 18(3), pp.227-244.

23. Farooq, M.S., Chaudhry, A.H., Shafiq, M. and Berhanu, G., 2011. Factors affecting students' quality of academic performance: a case of secondary school level. Journal of quality and technology management, 7(2), pp.1-14.

24. Fitsilis, P., Gerogiannis, V. and Anthopoulos, L., 2014. Ontologies for software project management: a review. Journal of Software Engineering and Applications, 7(13), p.1096.

25. Adams, J.D. and Jaffe, A.B., 1996. Bounding the effects of R\&D: an investigation using matched establishment-firm data(No. w5544). National bureau of economic research. 


\section{AUTHORS PROFILE}

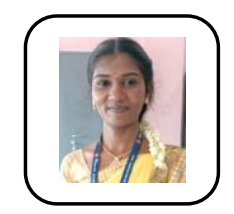

G. Vinothini Assistant Professor, Department of Science and Humanities, Bharath Institute of Higher Education and Research, Chennai, India.

R. Priya Assistant Professor, Department of Science and Humanities, Bharath Institute of Higher Education

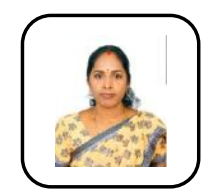

and Research, Chennai, India.

S. Jayanthy Assistant Professor, Department of Science and Humanities, Bharath Institute of Higher Education and Research, Chennai, India. 